Lфvborg, L. (in press) A portable $\gamma$-spectrometer for field use. Danish Atomic Energy Comm. Res. Establ. Ris $\emptyset$, Rep. No. 168. Sørensen, H. (1962) On the occurrence of steenstrupine in the Ilímaussaq massif, Southwest Greenland. Medd. Gr $\phi$ nland, Bd. 167, Nr. 1 .

Sфrensen, H., Hansen, J. and Bondesen, E. (in prep.) Preliminary account of the geology of the Kvanefjeld area of the Ilímaussaq intrusion, South Greenland. Rapp. Grфnlands geol. Unders.

THE FLAT-LYING METAMORPHIC COMPLEX AND RELATED IGNEOUS ROCKS OF THE KAP FARVEL AREA

\title{
J. Sutton and J. Watterson
}

$7000 \mathrm{~km}^{2}$ have been mapped on a scale $1: 100000$, in an area east of Frederiksdal $\left(44^{\circ} 40^{\prime} \mathrm{W}\right)$ extending $90 \mathrm{~km}$ northwards from Kap Farvel to the northern side of Lindenows Fjord $\left(60^{\circ} 35^{\prime} \mathrm{N}\right)$. The chronology previously established in the southern part of the area (Bridgwater, Sutton and Watterson, 1966) has been confirmed and found applicable to the whole area.

Much of the area is underlain by high-grade crystalline rocks derived from a supracrustal succession of predominantly clastic sediments. No crystalline basement has been recognised to this, presumeably Ketilidian, sequence which is several km thick. Metasediments range from impure quartzites to pelites and frequently contain sufficient calcium to develop minerals such as diopside; in spite of this characteristic high calcium content, marbles and calc-silicates are relatively uncommon except in the topmost part of the known succession. Graphitic and iron-rich horizons occur 
but do not exceed a few metres in thickness. No volcanic succession comparable in thickness with that of Tasermiut Fjord has been found; volcanic rocks, which include agglomerates, have been identified only in the fjord system north of Augpilagtoq.

The metamorphic complex is remarkable for its flat-lying structure and widespread development of a flattening-type fabric with no stretching or linear element, but containing recumbent isoclinal folds. Taken as a whole the supracrustal rocks of this and adjacent areas to the west define a gentle dome about $100 \mathrm{~km}$ wide. The succession appears not to have important complications due to the recumbent folding. The lowest members outcrop near Augpilagtoq and higher members are found on the flanks of the dome in three areas (Lindenows Fjord, Eggers $\varnothing$, Tasermiut Fjord) which cannot be readily correlated as they are separated from each other by younger igneous rocks.

A locally discordant subhorizontal granodiorite sheet, in places exceeding $1 \mathrm{~km}$ in thickness, is concordant on a regional scale and provides a convenient datum for division of the supracrustal rocks into an upper and lower series. This sheet, which has been identified over some $2000 \mathrm{~km}^{2}$, is bounded by spectacular zones of veins. The overlying zone is particularly well seen on the east coast near the mouth of Lindenows Fjord, where it forms a migmatite complex with quartzitic rocks which are veined by aplites and pegmatites up to $100 \mathrm{~m}$ thick. The lower zone of veins is also characterised by aplites and pegmatites which extend for several hundred metres through the metamorphic rocks underlying the sheet. This granodiorite is the largest of a group of older granitic rocks some of which, particularly in the neighbourhood of Lindenows Fjord, are sharply discordant.

Complementing the flat-lying disposition of the structural elements is the gentle inclination of regional metamorphic boundaries. The centre of the regional dome is characterised by granulite facies assemblages with garnet and two pyroxenes, and the higher parts of the succession by amphibolite facies assemblages. Variation in mineral facies is paralleled not only by differences in style and 
degree of migmatisation but also by variations in the character of the late-plutonic igneous rocks of the rapakivi suite. In the granulite facies area the igneous rocks are heterogeneous and seen to be in part derived by granulite facies ultrametamorphism and anatexis of the metamorphic series. In the structurally higher amphibolite facies areas the late plutonic suite is represented mainly by moderately to gently inclined sheets of homogeneous rapakivi granite. Disruption of the flat-lying regional structure is most marked adjacent to those members of the igneous suite within the highest grade metamorphic rocks. Steeply dipping and vertical country rocks bordering some of the late granites can be seen to be the result of downwarping of the regional flat-lying fabric. Flat-lying horizons which are at an altitude of $2000 \mathrm{~m}$ only $3 \mathrm{~km}$ from the contact of a $10 \mathrm{~km}$ wide granite, reach the contact at sea-level and with almost vertical attitude. The excellent outcrops provide repeated evidence of such collapse structures, in the development of which fracturing was subordinate to flow deformation. Although rocks of the rapakivi suite clearly post-date the regional metamorphism in the amphibolite facies areas, where superimposed thermal aureoles can be identified, some members of the suite were emplaced into country rocks in which granulite facies mineral assemblages were stable.

\section{Reference}

Bridgwater, D., Sutton, J. and Watterson, J.S. (1966) The Precambrian rapakivi suite and surrounding gneisses of the Kap Farvel area, South Greenland. Rapp. Grønlands geol. Unders., Nr. 11, 52-54. 